\title{
A REVITALIZAÇÃO DA FEITURA CERÂMICA GUARANI-MBYÁ NA TEKOA MBOY-Y-TY: UMA VIA DE REDESCOBRIMENTO E REAFIRMAÇÃO DO SEU ETHOS IDENTITÁRIO
}

\author{
Franklin da Silva Alonso ${ }^{1}$
}

\begin{abstract}
RESUMO: Durante toda nossa história nacional, sempre houve a interação sociocultural sistemática entre indígenas e a comunidade não-índia, muitas vezes criando a falsa noção de superioridade de uma sobre a outra. Daí, objetivei buscar a retomada das obras de barro Guarani-Mbyá na aldeia Mboy-y-ty pela metodologia de uma pesquisa-ação atuante junto às suas crianças, pois no Brasil (desde o século XVI) tal ação artística vem sendo desmobilizada pelo colonizador europeu e seus descendentes, nutrindo no senso comum uma ideia de enfraquecimento estético agregado às realizações concretas nativas. No decorrer desse escrito, perceber-se-á que os resultados obtidos nas oficinas cerâmicas com tais crianças hão de contradizer a mitologia escrita pela ótica etnocêntrica de sua fragilidade na formação cultural de nosso país, concluindo que o índio é sim um verdadeiro protagonista histórico, indivíduo altamente contribuinte para a estruturação de nossa sociedade.
\end{abstract}

Palavras-chave: Índios. Guarani-Mbyá. Cerâmica. Arte-Educação.

\section{THE REVITALIZATION OF THE GUARANI-MBYÁ CERAMIC MADE IN TEKOA MBOY-Y-TY: A ROAD OF REDESCREWING AND REAFFIRMING ITS IDENTITARY}

ABSTRACT: Throughout our national history, there has always been systematic sociocultural interaction between indigenous people and the non-Indian community, often creating the false notion of superiority over one another. Hence, I aimed to seek the recovery of the works of clay Guarany-Mbyá in the village Mboy-y-ty by the methodology of an action research active with their children, because in Brazil (since the 16th century) such artistic action has been demobilized by the colonizer. Europeans and their descendants, nurturing in common sense an idea of aesthetic weakening added to native concrete achievements. Throughout this writing, it will be understood that the results obtained in the obtained in the ceramic workshop with such children will contradict the mythology written by the ethnocentric view of its fragility in the

${ }^{1}$ Mestre em Artes Visuais pela Universidade do Estado do Rio de Janeiro (2014). Atualmente é professor de Educação Artística do Estado do Rio de Janeiro e Prefeitura da Cidade de Mesquita. 
cultural formation of our country, concluding that the Indian is indeed a true historical protagonist, highly contributing individual to the structuring of our society.

Keywords: Indians. Guarani-Mbyá. Ceramics. Art-Education.

\section{LA REVITALIZACIÓN DE LA CERÁMICA GUARANI-MBYÁ HECHA EM TEKOA MBOY-Y-TY: UM CAMINO DE REDUCCIÓN Y REAFIRMACIÓN DE SU IDENTIFICADOR}

RESUMEN: A lo largo de nuestra historia nacional, siempre ha habido una interacción sociocultural sistemática entre los pueblos indígenas y la comunidad no india, a menudo creando la falsa noción de superioridad sobre los demás. Por lo tanto, pretendía buscar la recuperación de las obras de arcilla Guarani-Mbyá en el pueblo de Mboy-y-ty mediante la metodología de una investigación de acción activa con sus hijos, porque en Brasil (desde el siglo XVI) dicha acción artística ha sido desmovilizada por el colonizador. Los europeos y sus descendientes, cultivando en sentido común, una idea de debilitamiento estético además de los logros concretos nativos. A lo largo de este escrito, se entenderá que los resultados obtenidos en los talleres de cerámica con teles con hijos tradecirán la mitología escrita por la visión etnocéntrica de su fragilidad en la formación cultural de nuestro país, concluyendo que el indio es de hecho un verdadero protagonista histórico. Individuo altamente contribuyente a la estructuración de nuestra sociedad.

Palabras clave: Indios. Guaraní Mbyá. Cerámicas. Educación Artística.

\section{De como, apesar de tudo, a força estrutural dos símbolos morfológicos e gráficos continuam importantes para os Guarani-Mbyá}

Parece contundente demais propor a reflexão de que o homem branco venha desde há muito - tentando apagar as marcas materiais e imateriais de nossos ameríndios. Então, até admito que não há nada mais justo do que arguir se haveria alguma veracidade nesse meu questionamento. Mas garanto-Ihes que sim e que aqui juntos veremos como essa alegação mostra suas bases espelhadas na própria história dos Guarani-Mbyá. 
Foi justamente para enfraquecê-los socioculturalmente que houve (desde o século XVI) uma contínua tentativa da sociedade ocidentalizada em buscar traçar um estereótipo de inaptidão sensível/intelectiva generalizada à realidade indígena. Haja vista que nossa cultura pretensamente superior "observa de cima" os hábitos de outros ethos sociais que lhes pareçam ser inconcebíveis e aponta somente seus próprios costumes como naturais e corretos. Muitas vezes referindo-nos aos indígenas, criamos ideias a seu respeito que vão do simplismo teor de sua inocência e pureza harmoniosamente relacionados com a natureza à sua volta - até às violentas ondas de crítica e aversão, desdenhando de qualquer atributo positivo que deles possam derivar. Inclusive, o fomento ao menosprezo por sua arte. Sim, a promoção a uma sistemática depreciação da arte indígena. $\mathrm{E}$, até comumente, para alguns nós, ela é totalmente ignorada de existência. Grosso modo, o senso comum ainda parece perceber $\mathrm{o}$ indígena como aquele que produz objetos apenas para sua sobrevivência física, acatando as necessidades imediatas do dia a dia sem apreço ao estético e, portanto, desprovido de qualquer fruição sobre o artefato criado.

Decerto que as elaborações concretas indígenas, como em muitos outros grupos humanos, têm seus aplicativos voltados para finalidades de alimentação (para a caça, pesca, recolhimento e guarda de víveres) e utilidades domésticas afins, como ainda as de moradia, transporte, lazer etc. Todavia, elas também apresentam elementos de ordem subjetiva que encarnam conjuntos de valores ultrapassando as feições utilitaristas - como, por exemplo, em seus rituais endógenos. E esses valores criam dimensões de significados presentificados no mundo por intermédio de sua tecnologia, ou seja, do seu fazer. Um fazer carregado de saberes associados entre si e que dão algum tipo de esclarecimento para seu homem sobre as coisas que o cercam. São assim, etnoconhecimentos formadores de seu patrimônio imaterial e que não podem se perder.

Ora, no decorrer da sondagem inicial para a definição de meu trabalho em ArteEducação a ser realizado no âmbito de minha dissertação de Mestrado (na TekoaMboy $y$-ty em Camboinhas, Niterói), foi que observei que os Guarani-Mbyá moradores dali a certo tempo não mais fabricavam objetos cerâmicos - com exceção do petÿngua, o cachimbo cerimonial do cacique e construído só por ele. Algo que de imediato nos desperta a pergunta do porquê essa ocorrência se manifestar. 
Este é um daqueles fatos aos quais podemos atribuir o desejo do etnocentrismo em sujeitar a cultura indígena, como brevemente aqui já tratado por mim. Foi devido a consecutivos e brutais ${ }^{2}$ contatos que os Guarani tiveram e ainda têm sofrido junto à população branca que esse dado cultural das feituras em barro foi sendo, gradativamente, deixado por eles de lado.

O professor e mestre em Etno-História Ivori J. Garlet e a Professora, antropóloga e doutoranda em Antropologia Social Valéria S. de Assis proporiam que os missionários diferenciavam sua prática atrativa dos demais europeus por ideologicamente blefarem contra os Guarani-Mbyá via pregação messiânica, eufemicamente oposta à enérgica ação militar. Nas reduções estava implícito o desejo branco de desmantelo cultural com intento de desmobilização do grupo indígena, facilitando seu domínio sobre ele. Dentro de uma redução jesuítica a sua presença não se dava pela existência de uma só nação ali mantida; o europeu impunha o convívio de diversas etnias indígenas em um mesmo lugar. Não sopesava as diferenças e rivalidades entre elas, fossem culturais, linguísticas, bélicas, religiosas etc. (GARLET; ASSIS, 2002, p.100).

Já as oficinas das missões promoviam, por exemplo, o incentivo sacerdotal na mudança material/conceitual dos construtos Guarani. Os padres buscavam a aceitação indígena de técnicas construtivas e decorativas que não debatessem com sua cristandade com motivos plásticos "pagãos". Nesse contexto, dizem-nos os arqueólogos Fernando La Salvia e José Proenza Brochado que, mesmo mantendo uma morfologia e pintura nos vasilhames similares àquelas Proto-Guarani, a proximidade com a feitoria cerâmica europeia demonstrada em trabalhos provindo das missões seria óbvia, pois com o uso do torno e da forja era comum perceber-se elementos na peça estranhos a sua tradição - asas, bico e fundo plano (LA SALVIA; BROCHADO, 1989, p. 121).

\footnotetext{
2 Vide que em 1537, os missionários católicos espanhóis buscavam almas panamericanas a redimir, enquanto os soldados, glórias e riquezas do lugar. Religiosos e militares ibéricos, sequiosos por enriquecimento pelas primícias naturais, dividiram as terras pelo Tratado das Tordesilhas e formaram batalhões de índios capturados para trabalhos forçados (nas encomiendas ou descimentos). Quando não cativos, a morte era o seu destino, o que fez com que os Guarani buscassem refúgio nas reduções jesuíticas nos meridianos sul-americanos. Todavia, ali os indígenas estiveram não apenas sob sua proteção física, mas sofreram o alcance religioso-ideacional dos padres.
} 
Confrontando seus artefatos ante o nativo, os homens ocidentais ensinariam a "aprimorar" as obras deste pelo uso de técnicas mecânicas de construção e retirariam as propriedades que caracterizariam essas peças como símbolos de uma comunidade específica, tentando substituí-las pelas suas próprias. Os trabalhos Guarani sofreriam naquele contexto de influência material e ideológica dos brancos pela imputação não mais derivativa da sobrevivência mediante o meio ambiente natural (e sobrenatural) e nem mesmo pelas cooptações realizadas junto a outros grupos selváticos. Não responderiam mais ao uso prático diário ou de celebrações ritualísticas, sendo resultados híbridos em tentar viver adequadamente no novo mundo que lhes fora imposto. Os ensinamentos nas histórias tradicionais indígenas de por que fazer algo de certa forma e de como e para quê fazê-lo - há séculos expostos de modo intergeracional - perderiam sua vitalidade e deixariam de ocorrer. A necessidade cosmogônica e de autorrepresentação bem como a de seu coletivo, sugere aos poucos deixar de existir como algo primordial às suas vidas. Descaracterizados, sua autoestima e reconhecimento como indivíduos importantes, detentores de uma cultura ímpar e igualmente mister para toda a estruturação nacional foi sendo minada, pois "[...] com o processo catequético onde adquire uma semi-imagem de homem 'pagão e pecador' que deve ser salvo [...]" acata que "[...] seus princípios 'mágico-religiosos' devem ser abandonados ou destruídos, ultrapassando-se aí, talvez, de um para outro tipo de decoração plástica e a busca de outros motivos mais 'aceitos e compreensíveis' pelo europeu, seu 'salvador'." (LA SALVIA; BROCHADO, 1989, p. 106).

Porém, com medo do retorno à vida escrava após a expulsão da ordem jesuítica do território sul-americano pelas Coroas ibéricas, os indígenas refugiaram-se nas matas ou buscaram se integrar nas cidades usando os saberes tecnológicos aprendidos nas reduções missionárias, tornando-se artífices. Sendo o trato do nativo com a cerâmica um dos ofícios "melhorados" nas missões, muitos acharam por seu meio a nova forma econômica de sobreviver nos centros coloniais: a arte tradicional indígena de trabalhar o barro - agora modificada - foi subornada pela força sociocultural do opressor.

Daí eu insinuar à época do início do trabalho de campo na TekoaMboy y-ty, haver a necessidade de relembrá-los de parte da sua própria tradição material argilosa hoje tida por muitos como "esquecida". Seja pelo motivo de intercâmbios étnicos mal direcionados, influências diversas decorrentes da atual substituição e apego indígena 
aos objetos industrializados mais práticos para cocção que os seus tradicionais, seja pela introdução de novas tecnologias para a criação de suas peças ou mesmo pelo comércio que se avulta mais e mais em seu seio societal como forma econômica de sobrevivência, a defesa dos costumeiros dados oleiros nativos pareceu-me ser um adequado projeto de permanente lembrança e, se necessário, até de resgate junto àqueles homens. Haja vista que, como citado, atrás de cada uma de suas manifestações, habitam etno-saberes sustentadores de sua realidade de vida.

Mas como fazer a promoção de um processo de revitalização e até reelaboração do trabalho cerâmico junto a eles? Símbolos gráficos da etnicidade Mbyá surgiam sob a forma de peças até recentemente atípicas à sua tradição material, como colares, saias e pulseiras feitas em miçangas (contas de plástico coloridas), mas que na atualidade - entre outros objetos mais - sustentam a economia criativa da tribo pelo seu artesanato. Convivendo com os Mbyá, percebi que os emblemas visuais de sua filosofia espiritual (e que eram antes manifestados na materialidade do barro) hoje têm também uma maior incidência no método de confecção e decoração de sua cestaria, na arte em madeira, no cardar de esteiras e em outras formas de seus procedimentos artísticos. O que não quer dizer que outrora esses símbolos étnicos fossem exibidos exclusivamente pela arte oleira, mas que com a sua notória escassez, tornam-se mais evidentes nos mais diversificados corpos. E, mesmo quando objetos e técnicas não correspondiam àqueles corriqueiramente regulares de sua cultura, esses signos plásticos continuavam se mostrando no seu coletivo. Essa é uma atitude que propõe ao nosso pensamento que os artigos contemporâneos pelos quais agora se expunham pudessem, aos poucos, se incorporar à insígnia de sua feição artística, tornando-as em breve também elementos tradicionais de seu povo.

\section{De como as adaptações materiais na arte Guarani-Mbyá são assimiladas para o comércio juruá}

Ora, se por alguns poucos parâmetros já aqui observados vemos que os GuaraniMbyá se destacam em sua cultura material para buscar aceitação de suas especificidades - ante as obtusas idealizações atribuídas a eles por nosso deturpado senso comum em que estereótipos como ade uma suposta ignorância/selvageria/ 
incultura foram naturalizados - também ainda é afirmativo que os índios procuram estar sempre atentos à defesa de sua etnicidade por meios gerais.

Sobre o mote de conservação e demonstração da sua identidade étnica, a professora e pesquisadora Ladeira (2008, p. 23) assegura que

as sociedades indígenas que vivem uma situação de contato sistemático criam formas para se apresentarem nos espaços do mundo que envolve o jogo de relações com a sociedade nacional, adotando as representações, genéricas ou específicas, que foram criadas para elas. Entre as genéricas, são veiculadas imagens de índios vivendo em harmonia com a natureza ou destruindo-a, conhecedores ou ignorantes da biodiversidade, pobres ou ricos, desprendidos ou combativos no que tange a defesa de terras. Entre as especificidades, cada grupo indígena ganha uma marca pela qual será reconhecida sua etnicidade e que o identificará (para sempre) perante o mundo da sociedade dominante.

Seguindo a mesma linha de raciocínio, mas aportando sua atenção ao prisma indígena de autopreservação físico/simbólica, as também professoras e pesquisadoras Isabela Nascimento Frade e Marluce Reis (2010) salientam que os Guaranis têm hoje seguido dois tipos de posicionamento frente ao processo de tentativas de erosão cultural provocado contra si. Um desses modos é expositivo, em uma clara resistência feita, bem marcado por procurar ante a interferência da alteridade "[...] reduzir a cultura, buscar suas formas essenciais, tornando-as contrastantes nesse diálogo cultural opressivo [...]". Ou seja, o Mbyá não se fecha no seu mundo, mas tenta apresentar pelo menos um mínimo de suas especificidades, criando uma ponte comunicativa com o homem branco. Já a segunda disposição, ao contrário, aposta que, para resguardar as suas verdadeiras virtudes dos brancos, deve reservar as mostras de sua cultura exclusivamente para o uso íntimo da tribo. Assim, aos nossos olhos ocidentalizados "[...] inversamente, tornando-as invisíveis [...]" (FRADE; REIS, 2010, p. 43). Isto é, aí o Mbyá se cerra no seu mundo e rompe com qualquer esperança de diálogo com aqueles que não tenham das mesmas origens que ele. Portanto, aos juruás ${ }^{3}$, os Mbyá da TekoaMboy y-ty se alinham ao primeiro pensamento quando expõem elementos visuais que aparentam ser muito próximos aos da nossa cultura,

\footnotetext{
3 “Os Guarani-mbya referem-se aos brancos como juruá. Quer dizer, literalmente, 'boca com cabelo', uma referência à barba e ao bigode dos europeus portugueses e espanhóis conquistadores. De todo modo, o nome juruá foi criado a partir do contato com os brancos colonizadores e passou, com o tempo, a ser uma referência utilizada genericamente a todos os não-índios" (LADEIRA, 2008, p. 75).
} 
"[...] assumindo as formas dominantes [...]" que preponderam em nosso meio (FRADE; REIS, 2010, p. 43).

No primeiro caso, verifica-se que o Guarani escolhe imprimir em suas representações um sinal étnico, selecionando qual propriedade estética reproduzida dentre suas gerações Ihe dará maior amparo por seu suposto "exotismo", ganhando enfim a visibilidade desejada diante da sociedade metropolitana. Uma bandeira de aceno que pode ser revertida em reconhecimento das e nas suas demandas de direito as terras, de respeito a sua identidade e igualdade social, de aceitação de sua cultura por parte dos brancos, inclusive, comercialmente. Daí se imaginar que também pode ser um requerimento pelo motivo socioeconômico, uma visibilidade voltada para a venda de sua artesania e que lhe garanta uma sobrevivência dentro do sistema hegemônico sociocultural juruá.

O Guarani da TekoaMboy y-ty percebe - e o demonstra por meio de suas obras - que apesar das aparências materiais transformadas pela aproximação intercultural, jamais deixará de ser quem é. Perspicaz, ao invés de afastar-se completamente do nãoíndio, fagocita da cultura material cosmopolita certos elementos, tomando por empréstimo alguns de seus dados plásticos. O Mbyá, não raro, busca ter acesso a esses subsídios, solicitando para si o mesmo direito de usufruir das benesses que acaso perceba neles existirem (formais e ideacionais), assim até facilitando o acesso de seus artefatos ao comércio - aqueles que creem ser mais aprazíveis ao gosto do homem branco.

O dado da precisão em se integrar na economia do homem citadino é relevante e não pode ser desprezado, até porque hoje boa parte dos recursos financeiros angariados na TekoaMboy y-ty é advindo do trabalho do artesanato. Nessa perspectiva, a arte Guarani expõe aspectos derivados da apropriação de especializações técnicas voltadas ao fazer estético municiando-se de aparatos que dialoguem com outros públicos culturais ao qual, principalmente pelo fator econômico, agora se destine.

Afora essa adequação, por um lado a arte nativa ainda se arregimenta por uma ideia errônea do preconceito juruá de que sua elaboração se localiza em uma escala inferior no totem da criatividade humana. Uma premissa que nasce de um outro contexto sócio-histórico muito anterior ao lluminismo do século XVIII (hierarquizador 
de saberes, especializando determinados conteúdos em disciplinas de estudos), sendo provinda do mundo grego que seccionava as artes em mecânicas das artes do pensamento (LA SALVIA; BROCHADO, 1989). Na primeira categoria encontravam-se as pinturas, esculturas e a música, enquanto na outra figuravam a filosofia, a retórica e a poesia.

No campo da arte, poderíamos assumir que artes mecânicas seriam comumente vistas como artesanato e que as do pensamento seriam aquelas tradicionais de uma sociedade ocidental estratificada. A arte indígena seria, grosso modo, assim um material de ordem mecânica onde "[...] o artesanato nasce do fazer, e [...] a arte, do pensar [...]" (FRADE, 2006, p. 42). Ora, mas para se fazer, não se tem que pensar? Ou a obra é resultante de uma inspiração divina, recoberta por uma áurea de realização ultra-humana, ofertada ao artista em um momento especial? Ou seria ainda ela espontânea, advinda do resultado acéfalo onde o gesto autômato apenas se ocupa, sem sentido e sem direção? Se respondermos positivamente a essas questões, decerto se justificaria então essa dicotomia absurda entre arte e artesanato ${ }^{4}$.

Bem, se acaso confirmada a iniciativa de trabalho artístico devotada à sua venda, mesmo assim não ficaria claro que o pensar indígena é sobremaneira astucioso? Ele não planejou, anteviu e realizou conforme aquilo que melhor se adequasse a meta que estabeleceu? Onde se encaixa aí o obtuso conceito de artesanato diferenciado da idealização de arte?

\section{Concisões sobre obra de arte, omoixikã, nhandereko e de porã: conceitos da cultura material Guarani-Mbyá que abraçam sua grandeza intangível}

Creio que sobre o que realmente devemos nos ater em atenção nesse sistema construtivo Mbyá é - independentemente da variação estética -, a conservação dos elos simbólicos e comunicativos existentes entre ele e a sua sociedade, sempre alimentado por sua noção de espiritualidade. O imprescindível não é manter o objeto morfologicamente imutável; é sim, garantir a permanência daquilo que está nele

\footnotetext{
4 "O pensamento em arte também nasce dessa operosidade, um fazer que se estetiza, que age e pensa na forma. E é por isso que a dicotomia arte e artesanato também é falsa: ela está a serviço da desvalorização do corpo, nega uma inteligência artística primordial, corporificada, organicizada e organicizante. Mesmo que puramente conceitual, um fato artístico acontece no mundo das coisas; as coisas virtuais são também constituídas a partir das relações concretas" (FRADE, 2006, p. 45).
} 
subtendido: o seu caráter de produto de uma crença que dá bases a todo um ethos de vida comunal.

Assim, há de se pensar que as práticas cotidianas que abordam tanto o profano quanto o sagrado em um patamar de integralidade (e, claro, das quais o processo artístico faz parte) fortalecem em muito as tradições culturais Mbyá, sendo iniciativas de um processo também educativo, mesmo que na aparência dos itens construídos e usados - em algum grau - algumas vezes não correspondam totalmente aos padrões esperados (por nós) para representar a sua cultura.

A crença em se conseguir transformar uma realidade em outra, parte da fé que o Guarani tem de que exista uma mesma vitalidade comum a todos, mesmo que expressa no mundo pelos mais diferentes corpos. Em situações apropriadas, essa energia se manifesta conforme o desejo de quem a conclama pela força de palavras, criando um espaço em que pessoas, natureza, artefatos e divindades se encontram.

Esta para nós, juruás, é uma região altamente subjetiva dos termos e intenções adequadamente enunciados pelo indígena, em que cada um desses itens exerce certo emprego, resultando enfim no seu compartilhamento e na agência de certos poderes dentro de um contexto "mágico". Afinal, as dimensões sociais, espirituais, econômicas, políticas e ecológicas se integram na visão de mundo desse indígena, participando de suas práticas cotidianas. O nativo não faz mais distinção entre a produção de um objeto utilitário e outro artístico; segundo o valor atribuído à sua necessária presença em uma relação desejada pelo Guarani-Mbyá é que pelas palavras, pelas peças e pelos demais seres terrenos e divinos, se criam imagens que poderão auxiliá-lo (e até representá-lo) e que, fornecendo-Ihe benefícios objetivos/subjetivos, darão significado à sua vida.

Logo, nesse sistema integrador de um estado relacional total percebido pelas imagens mentais que a cosmologia ameríndia lhes proporciona, as suas palavras e seus ensinamentos favorecem que as obras artísticas transitem entre os mais díspares campos da existência do sujeito. Reafirmo que, por consequência, essa circulação é traçada por vários lócus sociais, amparando a cultura Guarani para não desenhar um rasgo entre o que lhe seja considerado objeto artístico, objeto utilitário e/ou objeto cerimonial: tudo faz parte de um mesmo universo. Isso segundo o instante em que o artefato for invocado oralmente com tal designo pelo seu usuário (aquilo que aqui é nominado por mim como a palavra/imagem e o Mbyá chama de omoixikã). 
Mas enquanto o juruá percebe o território da arte por premissas de individualismo - rompendo seus próprios sentimentos com aqueles advindos das posturas comunais -, acabamos de constatar que no pensamento nativo a união desenhada entre sujeito, grupo, natureza (humana e ultra-humana) e objeto se espelham nos campos socioculturais por onde a arte também percorre. Ademais, é comum que nossa linguagem artística ocidental muitas vezes tenda a ser hermética (principalmente a partir da eclosão do Movimento Modernista), envolta por indicadores que exijam, para a sua plena compreensão, aportes explicativos a um observador leigo. Ora, isso é algo diferente das obras artísticas indígenas? Não de todo, pois para esquadrinhar e abarcar a mensagem por trás da morfologia das peças índias, o pesquisador há de se revestir de interesse, cuidado para não tornar-se parcial e ter a obstinação de analisar devidamente o que percebe advir do seu outro.

Digo isso porque, como já anteriormente insinuado aqui, é sob o nosso restrito prisma etno e eurocêntrico, que se exige que arte do Mbyá, por exemplo, tenha parâmetros próximos aos que reconhecemos, como se ela tivesse uma razão de ser condizente com a identidade do branco. O objeto de arte indígena, como infelizmente por muito tempo foi tratado nas sociedades ocidentalizadas, deveria estar à parte da realidade do homem metropolitano, e por fim, diante dele coisificando-se. Mas se assim o fizéssemos desconsideraríamos que para o dito "selvagem" existem padrões diferentes dos nossos e aos quais ele já respondeu de pronto no ato da sua criação estética. Ignoramos que, opostamente a nós, ele humaniza e põem em pé de igualdade - dependendo de sua finalidade - artefatos, deuses e seres humanos. Há algo nessa sua criação que, portanto, normalmente nos escapa, haja vista que não somos (por mais que queiramos) culturalmente habilitados a apreender por completo essa heterogeneidade, sua ótica e suas emoções diante da vida.

Inclusive, Lagrou (2009, p.75) nos lembra sobre as desiguais perspectivas da idealização do termo "obra de arte" promovida tanto pelo homem cosmopolita quanto pelo indígena e onde

[...] o lugar que os objetos poderiam ocupar na escala valorativa instaurada pelo mercado das artes e pelos museus não necessariamente pertence ao universo das intenções e valores nativos que podem visar a objetivos muito diferentes dos ligados a conquista de visibilidade ou afirmação de identidade e "autenticidade". Assim, a fonte de inspiração criadora ou a legitimidade de motivos e formas estilísticas costuma, no pensamento ameríndio, ser visto 
como originalmente exterior ao mundo humano ou étnico, remetendo a conquistas sobre o mundo desconhecido, de vizinhos inimigos e seres naturais e sobrenaturais hostis e ameaçadores.

A arte indígena se ajusta então no compartilhamento de seus signos para alcançar uma equânime comunicação entre os seus parceiros, sejam eles humanos, ultra-humanos ou mesmo objetos. E é assim que o sujeito Mbyá desenha um sistema ideacional em que sua expressão artística pode viver em todas as suas realidades, onde o índio a lança intencionalmente para zonas de trânsito nas atividades do seu cotidiano. Deste modo, o nativo também coopera com as suas produções no conjunto do mundo, nele se afirmando como participante ativo junto com as outras coisas que compõem esse mesmo universo. Consequentemente, o conceito de beleza para esse homem estaria acoplado ao imediato uso do artefato - já que esse procedimento lhe traria satisfação (porã) -, independentemente da função que lhe fosse atribuída no momento de sua implementação, fosse ela trivial ou cerimonial.

Desta maneira, parece que, enredada nas condições mnemônicas e totalizantes de sua organização grupal, a associação entre arte e vida indígena (mundana/espiritual) é absoluta, desconsiderando segmentações como normalmente fazemos. Logo, não existe propriamente a concepção de obra de arte no pronunciamento Guarani-Mbyá. Há sim, a noção de dispositivos que contribuem no alcance da satisfação e regozijo por intermédio de afinidades, de elos criados em situações determinadas em que os artefatos, tais como os seres humanos e divinos, estão em condições favorecedoras à sua exultação harmoniosa com o cosmos. E aí a materialidade da arte indígena pode, tranquilamente, ser sorvida pelo território da sua imaterialidade.

Corroborando a essa assertiva, Frade se propõe a analisar o aspecto da desmaterialização dos objetos tornados vivos e emblemáticos a uma sociedade, destacando que "estamos imersos em um ambiente onde o signo tem muito mais valor que o real, onde a relação com a realidade das coisas se desfaz em estímulos luminosos cambiantes. A desmaterialização é um processo em aceleração [...] tudo flui" (FRADE, 2004 , p. 21). Analogamente a tal alegação, a arte e seus signos usados, então longe de ser categorizada pelo índio como utilitária ou contemplativa, é pensada por ele como parte da vida comunal e da sua identidade, e em contrapartida, a sua vida também é vista como item de sua arte. A arte, como diz Frade, flui pela significação que detém 
na conjuntura sociocultural de um grupo, considerando que tanto o aspecto tecnológico quanto o simbólico estarão de acordo com os seus costumes, com a sua inter-relação estabelecida frente à natureza, com sua língua e sua história. E, nesse contexto, a estima das peças se dá a partir do seu elemento essencialmente simbólico e não material. Para os Mbyá, seres e objetos não são assim tão-somente representativos de uma função, mas muito além disso, estão miticamente imbricados na existência daquela comunidade como meios para o alcance de um conhecimento, reconhecimento e, enfim, de um contentamento e até mesmo, como extensões do corpo físico de seus possuidores/utilizadores.

Diante de tudo isso não nos parece que a arte do índio Mbyá trabalha envolta por uma rede de crenças que tece atenções tanto à sua cultura material quanto à natureza incorpórea na qual está imersa? Não nos parece que o dado simbólico é imprescindível para que a expressão artística do nativo se mostre e se faça valer em suas vidas? Sim. O que aparenta é que, dentro do ambiente onde não há secção clara entre as funções determinadas dos artefatos, os "objetos ritualísticos existem na dimensão do sagrado. Deles emana a 'aura' divina. Essa é a origem da arte [...]" (FRADE, 2004, p. 20).

Consideremos ainda a admissão das possíveis mudanças ocorridas na tecnologia da arte cerâmica Guarani, fato levantado por La Salvia e Brochado (1989) e nos instigam a pensar - por meio de seus estudos arqueológicos - um pouco mais sobre esse elo criado entre os indígenas, os objetos de barro e o processo de dinamismo sociocultural que outrora se manifestava na sua sociedade.

Reconhecendo a ânsia humana em prover-se de elementos técnicos facilitadores à vida nativa, eles nos dizem que

sendo a cerâmica um elemento tecnológico determinante de um comportamento, nossa proposição é ver o homem que desenvolve uma tecnologia como satisfação de suas necessidades e inserido dentro de um contexto ecológico [...] determinando comportamentos distintos, dentro de uma mesma tradição cultural (LA SALVIA; BROCHADO, 1989, p. 5).

Recordemos então que essa satisfação não se restringe apenas a algo imediatista de sobrevivência, pois emerge de um universo integral, relacional entre homem-natureza, homem-objeto, homem-homem, homem-divino. O comportamento exultante que os Mbyá chamam deporã. Tendo então por alicerce a sua cosmologia - 
na qual se acredita na ligação entre o meio e os seres que nela habitam e operam -, a postura Guarani-Mbyá de interação diante da vida se faz crucial, reputando haver um equilíbrio natural no universo. Suas mitologias abonam que cada ser tem vigor comum, inspirado e exteriorizado sob formas e traços realizados nos corpos (mesmo que as diferenças externas entre os elementos sejam por eles admitidas).

Para eles, a palavra/imagem inspirada (omoixikã) projeta o futuro, e o futuro é escrito pelo Guarani só quando a diz com intenção de remeter sua força no sentido da matéria que a acolherá, criando um espaço de participação ativa na sua realidade. Os indígenas, a palavra e o artefato são atores construtores do presente/futuro. Assim, o que um artigo é hoje dentro de certa situação sociocultural indígena já é resultado do que eles, simbolicamente, determinaram ontem. Esse mesmo objeto pode vir a ser outra coisa amanhã, ter outra significação dependendo do desígnio da palavra que poderá ser dirigida a ele pelo Mbyá. E o pronunciamento aí se mostra como uma forma/força utilizada que possibilita a exploração, o sentimento e a sua expressão no mundo por uma conduta que, para esse coletivo indígena, os favorece a alcançar algum tipo de alegria pessoal, de júbilo para si ( $\left.v y^{\prime} a ́\right)$. Logo, fica muito claro que o item nativo, como um patrimônio identificador do seu grupo "[...] transita entre o material e o imaterial, reunindo em si as duas dimensões. O material e o imaterial aparecem de modo indistinto nos limites dessa categoria [...]" (GONÇALVES, 2005, p. 21).

Essa atitude dos Mbyá ratifica o que é o seu jeito adquirido diante da vida, conforme a direção seguida nas normas sociais estabelecidas por essas suas palavras abençoadas. Como afirmam Frade e Reis (2010), esse procedimento faz parte do que é o seu nhandereko (ou teko) ${ }^{5}$, isto é, a forma de ser do Guarani, aceitando,

\footnotetext{
5 "Quase todos os guaranis que eu conheço se referem à sua própria cultura, àquela que os identifica como povo, como um "ñande reko", que significa "nosso modo de ser, nosso costume, nosso sistema e condição, nossa lei e hábito". É claro que cada um desses diferentes povos coloca traços específicos em seu modo de ser: sua língua tem características próprias que a outra, de outro povo guarani, não tem [...]. Diga-se o mesmo de sua cestaria, de sua cerâmica, de seus rituais religiosos, do lugar de culto, de seus instrumentos musicais etc. Mesmo assim, é possível falar de um índio guarani genérico e uma cultura guarani. Ele é migrante, mas ao mesmo tempo é agricultor, vive em comunidades ou aldeias, sua organização social fundamental é a família extensa, governa-se mediante assembleias (aty) pequenas ou grandes, reconhece líderes religiosos e/ou políticos, tem uma religião baseada na palavra inspirada Pelos de Cima [Los de Arriba], palavra que se faz sacramento também mediante o canto e a dança, e se rege por eventuais profecias, entre as quais a chamada busca da terra-sem-mal teve preponderância" (MELIÁ, 2010, p. 54).
} 
coexistindo, ocupando o seu lugar e não se deixando apagar enquanto participante de sua cultura. E os objetos - independentemente de sua origem material -, fazendo parte de seu nhandereko, incorporam os significados que Ihes foram atribuídos pelos mitos por intermédio da palavra/imagem (omoixikã), tornando-se uma unidade na qual a arte/vida é uma garantia de acordo entre lugar, homens, animais e uma "dimensão superior" de existência (donde provêm os seus demiurgos).

\section{Da metodologia em Arte-Educação adotada na TekoaMboy y-ty}

Agora, retornando à pergunta que fiz no princípio desse escrito do como poderia resgatar a arte oleira junto aos Mbyá, considero que inicialmente eu deveria procurar melhor conhecer a realidade deles para buscar de alguma forma entender e favorecêlos. Creio que, aceitando seus conceitos de omoixikã, nhanderekoe de porã, melhor minha visão sobre suas percepções se daria.

Diante do quadro onde a cerâmica já foi vista pelos ascendentes Guarani-Mbyá como instrumento de satisfação (porã) aos seus imperativos é relevante buscar o revigoramento desse capital cultural porque ele sempre se mostrou no ambiente da vida indígena como um elemento de considerável perpasse ideacional, criando figuras mentais que os guiassem no sentido de manter um determinado ethos e os conduzindo para obter sua almejada felicidade ( $\left.v y^{\prime} a ́\right)$.

Mas, como eu deveria operar em uma ação de informação/formação intercultural focada na recuperação dessa expressão? Naquele momento inicial de trabalho, a única conclusão a que podia chegar era a de que, se estudava o prisma artístico no contexto sociocultural daquele povo, tinha que melhor conhecê-lo para com ele significativamente vir a agir.

Já ressaltei que, para os Mbyá, ambas as instâncias de um objeto - objetiva e subjetiva - se interpenetram dependendo da intenção e do momento da ação praticada. E, nessa situação, os códigos morfológicos e gráficos neles usados pelos indígenas podem significar não ser apenas banais adereços: eles podem se lançar no mundo como instrumentos de comunicação e ensinamento entre os agentes envolvidos. Mas não somente eles: a própria evocação oral de sua presença e uso cria apalavra/imagem, figura mental que vai amalgamar o incorpóreo (energia emitida) aos corpos (materiais receptores). Deste modo, pelo item cultural construído os sujeitos 
Guarani-Mbyá se reconhecem, pois aí há uma ressonância entre o processo do homem em fazê-los tanto quanto no de, posteriormente, se ver espelhado nessa mesma construção (individual e comunalmente) e de perceber a materialização de seus desejos e de sua identidade naquilo que foi realizado ${ }^{6}$.

Portanto, lembremos que na visão cosmológica Mbyá tudo está fortemente ligado, criando uma trama onde os seres (animados e inanimados) mutuamente se sustêm, fortalecendo episódios as suas existências por benefícios e até, por que não, por eventuais malefícios provocados a partir de suas condutas. $E$ as ações que advêm de seus demiurgos e/ou espíritos - personas que são representações de fenômenos que vão muito além da nossa insensível inteligência - decorrem dessas atitudes orais/atitudinais que os indígenas tomam.

Por essa percepção que as peças artísticas participam de um sistema de integralidade cosmológica que, por um prisma pedagógico respeitoso aos seus conceitos, conjecturei à época a precisão de um método específico a ser aplicado nas oficinas cerâmicas na TekoaMboy y-ty valorando a atividade artística não só como habilidade técnica de construção, mas como uma relevante práxis reflexiva e identitária do modo de ser Guarani (nhandereko) para quem dela se instrumentaliza.

Contudo, antes de falar do método de trabalho, sou obrigado a contextualizar a situação em que me encontrava nesse ponto da pesquisa.

Como resultado de meu contato de aproximação com os Guarani-Mbyá para iniciar as atividades que propunham a revitalização dos artefatos de barro, procurei a representação política da Tekoa (D. Lídia, a pajé e orientadora espiritual e por seu filho Darci, o cacique da aldeia. Com eles averiguei se existiria ou não o interesse do grupo para se criarem ações dirigidas à retomada do suporte argiloso. Esse retorno obtive logo depois, pois segundo eles tal assunto deveria ser primeiro decidido pelo coletivo Mbyá (aty)). Portanto, após esse consenso grupal, admitiram a validade e importância do projeto, ressaltando a oportunidade de revigorar um dos símbolos plásticos tão substantivos de sua cultura. Só a partir dessa sondagem inicial e de seu aval é que pude solicitar a concessão de um espaço na aldeia para executar meu plano de trabalho.

${ }^{6}$ Gonçalves (2005, p. 20) traduz o pensamento de Stephen Greenblatt para indicar que "por ressonância eu quero me referir ao poder de um objeto exposto atingir o universo mais amplo, para além de suas fronteiras formais, o poder de evocar no expectador as forças culturais complexas e dinâmicas das quais ele emergiu e das quais ele é, para o expectador, o representante". 
Entretanto, depressa me foi esclarecido que eu deveria considerar outro fator importante de sua realidade para buscar o retorno ao fabrico do item cerâmico. Além de não ser mais ali registrado o seu trato costumeiro com a argila, havia uma exigência crescente do mercado local pelo seu artesanato indígena (que economicamente os sustinha), fazendo com que, visando à venda imediata, sua atenção estivesse voltada à produção de objetos étnicos que lhes fossem "fáceis e rápidos" de construir. O ciclo de consumo que thes era impetrado pelo Juruá nesse sentido requeria deles uma elaboração de artefatos em escala considerável e, por consequência, de um tempo suficientemente grande destinado para que esse suprimento se desse. Os Mbyá adultos, comprometidos com a obtenção de recursos financeiros que mantivessem a Tekoa, não podiam, portanto, se ater demoradamente na construção de itens que necessitem de um período mais longo para a sua realização, como o caso da obra cerâmica. Ramos, a respeito das relações econômicas percebidas e agenciadas pelos indígenas e que vem cada vez mais se estabelecendo nesses contatos interétnicos, ressalta que "em situações de contato é comum desenvolverem-se dois tipos de relações econômicas: um acionado para fora, outro para dentro [...] nas trocas interétnicas prevalece o sistema mercantil monetário ocidental" (RAMOS, 1988, p. 40).

Deste modo, para prover o seu comércio com o branco, obras dedicadas a cestaria, sua arte plumária, miçangas feitas com sementes e contas de vidro coloridas, estatuetas animais e arcos e flechas feitas em madeira, Ihes pareciam mais práticas em serem feitas. Já a arte cerâmica demandaria prolongado tempo para seu fabrico, sendo este exigido no seu processo laboral e no seu necessário esmero tridimensional/ pictórico, comercialmente contraproducente no objetivo da obtenção imediata de dinheiro. E aí volto a refletir sobre a pergunta que fiz logo no título desse escrito: de certo modo, mesmo que de forma não intencional, já não haveria aí um resquício mnemônico de tentativa branca de desmobilizar as realizações indígenas (tangíveis ou intangíveis)?

Agora conhecendo essa atual realidade criada na relação pecuniária com o juruá, entendi por que homens e mulheres Mbyá pouco se mostravam dispostos a aderir à ideia de revisitar na prática essa tecnologia. Estando eu pronto para dar andamento ao projeto, me encontrava, em meio a um dilema onde apesar de ter pessoas interessadas em reavivar a arte em barro pelo que ela ancestralmente 
significa, em contrapartida relutavam em abraçá-la, pois não dispunham de tempo hábil para o seu exercício.

E foi pelo estudo do método da pesquisa-ação que fui levado a perceber que certas adaptações careciam ser realizadas, com as metas revistas e ajustadas conforme as circunstâncias com a quais eu me deparava no meu trabalho. Fiquei então à disposição de quem quisesse agir comigo, me mantendo no único lugar arranjado para receber todos os que estivessem possibilitados a participar das atividades oficineiras: a escola indígena da Tekoa.

Imediatamente os que para a escola se dirigiram foram as crianças, fazendo a pesquisa ganhar uma identidade de atendimento focada para um grupo mais restrito na faixa etária, o que não fora inicialmente previsto por mim. É cabível aqui explicar que esse público foi sempre muito flutuante, já que os Guarani têm uma característica de fundamento mítico da sua não permanência em apenas um local, mas sim em manter constante mobilidade territorial, criando uma rede espacial de vivência, um multiterritorialíssimo ${ }^{7}$. De tal modo, devido aos deslocamentos das famílias, comecei o trabalho de oficinas com doze Mbyá (de quatro a onze anos de idade). Destes, apenas oito permaneceram e, posteriormente, se estabeleceu um número oscilante que ia desta margem até cinco índios. Com as informações arqueológicas, etno-históricas e estéticas sobre essas suas obras telúricas ancestrais que eu levava até eles em nossos encontros, abriu-se a chance de desenvolverem peças correspondentes àquelas de sua tradição e outras mais que, segundo seus desejos, mostrassem até novas características pelos dados morfológicos.

$\mathrm{Na}$ oportunidade, perguntei a eles sobre o assunto "arte", sobre o que entendiam pelo termo, se já haviam ouvido dela falar. Todos ficaram muito reticentes em se expressar, até que o cacique Darci deu sua opinião dizendo que ela é "todo tipo

\footnotetext{
'Lewkowicz e Pradella (2010, p. 83) argumentam que "[...] O entendimento mbyá-guarani de um território passa pelas relações constituintes das pessoas, estabelecidas em diferentes espaços. As leituras das paisagens se dão conforme a presença ou a ausência dos seus parentes humanos e das divindades com as quais buscam religiosamente restabelecer relações, mas também na ausência e presença dos outros (o que em antropologia chamamos de alteridades) que povoam o cosmos: são eles os animais, os vegetais, os não-índios, outros grupos indígenas, os mortos e uma variedade de outras entidades. A mobilidade, chamada pelos guaranis de jeguatá (caminhar) é, portanto, elemento constituinte da forma tradicional de lidar com os seus e os outros, marcando através de aproximações e distanciamentos a ocupação e ralação com os espaços [...]".
} 
de saber que é traduzido em formas de objetos" - intervenção incitadora para discutirmos um pouco, pois ele logo reconheceu a importância de manter a lembrança comunal Mbyá expressa pelas mais variadas mídias (como a artística) para que sua cultura não viesse a ser desmantelada frente às relações interétnicas diariamente sucedidas. Darci cria que pela linguagem das artes seria acolhida de uma forma mais criativa a memória dos fatos e ações subjetivas relativas ao etno-saber cosmológico do grupo. Isso, porém, segundo os recursos materiais que atualmente esses índios disporiam para elaborar as suas obras. Uma observação relevante, pois a Tekoa estava assentada sobre um areal, terreno que não favorecia a apropriação natural de barro. Apesar de terem às suas costas a Lagoa de Piratininga, esta, segundo sua alegação, é poluída, o que não ajuda no recolhimento desse insumo. Logo me comprometi a fornecer a matéria-prima para que as ações pudessem ocorrer. Não esqueçamos, entretanto, que no condizente a questão artística não há definição indígena que combine exatamente com a ideia de "arte". O que há de mais próximo a tal argumento é o termo porã, instância conjugadora de atributos tais quais a presteza, beleza e a satisfação que o elemento evocado suscitaria e que deve ser sempre preservada pelo Mbyá - como bem salientou naquele episódio o cacique.

Já no meu segundo encontro com os Mbyá não tive a participação esperada dos adolescentes e adultos como imaginei. Na verdade, não surgiu nenhum deles para as ações de trabalho pretendidas. Só depois fiquei sabendo que aqueles que eu considero como adolescentes, dentro da cultura Mbyá, passam a serem vistos como adultos a partir dos quatorze anos de idade. E o seu foco principal, como adulto, é o de cumprir com as responsabilidades sociais diárias as quais, nas suas atuais circunstâncias econômicas de busca e manutenção pela sobrevivência, não Ihes permitiam ter tempo para realização de mais uma nova empreitada.

$\mathrm{Na}$ atuação citada acima, os meninos receberam um pedaço de barro conforme o tamanho de cada um: criança pequena torrão pequeno; criança maior torrão maior. Seguidamente, sentadas em roda sobre jornais forrando o chão, solicitei que desmanchassem aquelas pedras. E no início dos trabalhos avento sempre ser necessário ter com os participantes uma conversa explicando a proposta do dia, pretendendo que eles sabiam o contexto do porquê estarem desenvolvendo determinada ação. Isso Ihes dará durante o processo do acontecimento construtivo, 
amparo à evocação de sua imaginação e de sua sensibilidade. Assim, enquanto trituravam a terra (impactando os torrões contra o solo), fui explicando que aquela porção de terra era formada por outras pequenas pedrinhas que juntas formavam a argila (nhaiu).

Depois de trituradas essas pedras, cada um pôs seu pó resultante em cumbucas plásticas que distribui. Porém, antes da próxima ação, perguntei o que achavam que poderíamos fazer com esse resíduo para conseguirmos um material mais mole. Como no início de toda atividade, ficaram tímidos e tive que responder que para conseguir isso os colocaríamos na água. Saímos da escola indígena e fomos para a bica externa onde cada um botou em seu pote com pó um pouco de água.

As conclusões as quais alcancei até aquele momento era a de que, para que os participantes pudessem dirigir bem sua artesania com o barro, seria imperativo primeiro obedecer à natureza daquele insumo, sendo preciso melhor conhecê-lo. E foi recebendo-o em forma de pedra para triturá-lo e agregando um pouco de água para torná-lo mais maleável que, creio que além de ter favorecido os jovens à percepção na transformação da matéria-prima, instiguei também uma situação onde pudessem manipulá-lo, sentindo sua textura, peso e plasticidade. Nesse ponto do trabalho, o intento era o de estimular a sensibilização dos pequenos Mbyá na observação da mudança de estado físico do insumo argiloso, dando-lhes a chance de analisar a sua variação, quando avaliamos juntos o fato ao final de nossa reunião - uma ambiência pedagógica relativa à Arte-Educação ali aplicada. Como percebido e dito por um dos meninos: "a terra fica mole quando é molhada, que nem em dia de chuva".

De tal modo, na terceira etapa da atuação oficineira, depois de relembrar o porquê de a argila estar mole, comentei com eles sobre o passado da construção cerâmica Guarani. Falei que seus ancestrais faziam múltiplas formas de recipientes através do processo de acordelamento, pois a Etno-História desse povo nos assegura que "[...] o mais usual e encontrado nos sítios arqueológicos e nas amostras estocadas é a produção do cordel de argila e a superposição dos mesmos, nos dando o início de todo o processo de produção [...]" (LA SALVIA; BROCHADO, 1989, p. 20). Não usei esses termos com os curumins, dizendo que os antigos índios Guarani construíam seus potes, panelas, cumbucas etc. a partir de "cobrinhas" de barro. Utilizei expressões com elementos animais durante esse procedimento de construção já que, sendo na sua 
maioria crianças pequenas e acostumadas em conviver com esses tipos de seres, possivelmente pela linguagem, criaria uma maior compreensão naquilo que thes estava sendo proposto. Nas oficinas, esperei que tal espaço se tornasse cada vez mais intimista e aconchegante, onde teria por fim um retorno desses índios (um acervo imagético/memorial de obras em barro), mas sempre pautado pela ética e compromisso, retribuindo-lhes com subsídios efetivos do que por mim fosse averiguado e, assim, melhor podendo auxiliá-los naquilo que eles identificassem como precioso à sua plena satisfação ( $\left.v y^{\prime} a ́\right)$.

Logo cada um teria um punhado de "cobrinhas" de barro em mãos para começar o seu trabalho artístico. Sugeri fazer um pote (karo), mostrando-lhes como elaborá-lo através da minha ação prática. Cada qual, munido com suas "cobrinhas" argilosas, passou a imitar meus gestos, construindo a base da cumbuca. Deste modo, os convidei a pegar um dos roletes e a enrolá-lo como se fosse um "caracol". E, tendo o "caracol" como fundo da peça, pedi que assentassem outra "cobrinha" nas suas bordas para, sucessivamente, levantarem as paredes do karo.

Com essas explicações básicas construímos em conjunto os potes com certa facilidade, tendo a participação de todos os presentes, dos pequenos aos maiores. Isso talvez ocorrido porque é no coletivo que se favorece o domínio e a interação de diálogos estabelecidos com nossa alteridade. Por isso, até posso crer que este tenha sido um trabalho feito com felicidade, desta vez os vendo menos contraídos, conversando e rindo ao mexerem com o barro. Tanto o é que, ainda durante o método de construção dos karos, alguns dos jovens maiores começaram a fazer por conta própria figuras de argila como bonecos, o contorno de um caminhão, uma moto e panelas. Ressalta-se que, ao final do processo construtivo, ainda lhes sugeri que fizéssemos um tratamento superficial simples em suas peças (técnica do alisamento), trabalho muito bem acolhido pelos Mbyá. Dessa maneira, durante a construção dos potes, notei a ativação e mobilização de sua criatividade. Os meninos se detiveram a construir outros itens que não àqueles previamente orientados por mim. Os indícios de sua percepção, de sua criticidade, de autoavaliação do seu trabalho parecem aí já surgirem.

Com a participação dos curumins na oficina cerâmica é que pude então perceber que suas atividades deveriam ir além da minha tentativa de lhes trazer apenas noções 
construtivas sobre os artefatos argilosos de seus antepassados. Até porque, nas tarefas oficineiras, um dos dados substanciais a se extrair dali parecia ser o efeito da descrição mitológica que as crianças ouviam dos mais velhos na Tekoa, o como (na sua expressão sobre o objeto de barro) o mito nelas organiza imagens internas e as quais a elas, os pequenos Ihes atribuíam sentidos.

Mas, considerando a sua atual realidade de contato conosco (os juruás), é crucial ser notado também como as crianças vão lidar com o que recebem de informações da sociedade não-índia. Assim, esses jovens haverão de estar em meio ao dilema de compreender as estruturas narrativas e os simbolismos do que lhes são perpassados pelas duas culturas, a de seus ancestrais e aquela outra com a qual tem acesso e envolvimento diários: a cultura branca. Uma ilustração disso é a implementação plástica do elemento "asa" em algumas das panelas e copos realizados na oficina.

Pelas mostras materiais conseguidas nesse trabalho oficineiro, comecei a especular sobre a conjugação das soluções daqueles meninos para melhor estreitar e compartilhar saberes com seus parceiros de trabalho, ação esta também acrescida do seu conhecimento aproximado à sociedade juruá envolvente. Isso sem esquecer que, como participante dessa sociedade, de algum modo, também contribuo naquelas atividades para a transmissão de concepções que me são familiares, queira eu fazê-lo ou não. Algo que demanda que meu cuidado seja redobrado quando atuo com eles.

Assim procedendo, eles me fizerem imaginar que o processo começado pelo insumo barroso naqueles encontros os pudesse conduzir ao compartilhamento de questões-chave de ponderação e percepção na possibilidade de usá-lo, demonstrando formas não apenas tradicionais, mas também com e por inovações morfológicas. Creio que esses meninos foram auxiliados no seu desenvolvimento e aprendizado sobre a cultura cerâmica ancestral Guarani, ampliando ainda mais essa perspectiva, ajustando e dominando tanto as ideias e materiais de uma sociedade quanto às da outra, dandoIhes enfim significâncias efetivas em suas vidas.

Portanto, para mim, tais resultados parecem ser advindos de uma visão ativa dos pequenos Mbyá que perpassa por contextos baseados nas ideologias firmadas por sua própria educação mitológica, tanto quanto também daqueles dados fornecidos cotidianamente pelas suas trocas de experiências com os juruás e seu universo 
sociocultural - haja vista haver os karos de um lado e as motos e caminhões de barro de outro.

Assim, percebo que seja lá qual for a sua iniciativa predatória sobre a cultura ameríndia, o juruá não conseguirá invisibilizar toda a gama de informes do grupo Guarani, pois suas próprias crianças demonstram, mesmo que em um ato não intencional de resiliência, que o homem nativo sabe como se ajustar e equilibrar com inteligência as diversas facetas do mundo que habita. Ele pode - e deve - mover seus préstimos a sua tradição sem desvincular-se de tudo que o circunda, ou seja, do mundo branco. Como Frade e Reis (2010) aventam, O Guarani-Mbyá tem a possibilidade de fagocitar o que de melhor identificar no mundo do juruá e trazer para a sua vida, a cargo de conseguir uma vy'á.

Ou seja, as atividades de trabalho cerâmico teriam o intuito de, pelo conhecimento sociocultural de seu passado junto aos dados que tem do presente, fomentar uma atuação consciente e política por parte do indígena com bases perceptivas e então por ele racionalizadas visando o seu ethos-futuro. 0 curumim não poderia tornar-se assim, um examinador emancipado tanto no ambiente vivido quanto naquele também contatado, sendo propositor às novas formulações, reconstruindo seu patrimônio histórico-cultural a partir do que conhecesse? E, se quisesse, não poderia também expor o parecer de suas reflexões em formas e cores a sua heterogeneidade?

Seguindo com a análise dos encontros cerâmicos na aldeia, mas agora operando com um amparo bibliográfico arqueológico e etno-histórico, encaminhei-me para a apresentação às crianças de fotografias de seus objetos ancestrais de barro a partir da obra "Cerâmica Guarani” dos autores La Salvia e Brochado (1989).

Juntos, confirmamos que os trabalhos do povo Guarani de antigamente se pareciam muito com aqueles que os alunos haviam produzido nas oficinas (mesmos ainda sem ter tal consciência). Curiosamente, os pequenos potes (karos) e cachimbos (petÿnguas) mostrados no livro coincidiram na sua forma com alguns exemplares que ali já haviam sido feitos por eles, mesmo que os jovens ainda não tivessem o experimento visual prévio da morfologia de tais peças.

Relembremos que estas produções partiram da única orientação que lhes dei até aquele momento e que foi a do processo de construção via acordelamento. Daí em 
diante, por conta de sua imaginação, os meninos desenvolveram as demais configurações. Nessa oportunidade, surgiram as imagens de barro do animal cobra (mbo'y) e da tartaruga (karumbé). A primeira é símbolo da etnia Mbyá-Guarani, acreditada como dotada de poderes derivados das esferas celestiais. A segunda está relacionada à sua ideia de paciência e sabedoria ancestral.

$E$, já que o homem vive em sociedades onde a expressão primeira é a da imagem e das suas devidas reproduções, depois dessa constatação de similaridade existente entre aquelas formas cerâmicas ancestrais e as que os pequeninos Mbyá produziam, mostrei ainda com o auxílio de fotos do livro de La Salvia e Brochado (1989) a decoração ungulada (com impressões da unha) feita pelos Guarani de outrora e propus que fizéssemos objetos com tal incremento. Porém, se faz necessário observar que nem todas as crianças seguiram esse norte construtivo. Tivemos alguns resultados de apropriação dessa mesma proposta por alguns deles (notadamente, os maiores).

Observa-se também que aí já incluíram em seus karos elementos formais intrusivos, supostos do permanente contato com os utensílios de cozinha dos nãoíndios: alças e (agora) bicos. Também se pode salientar que as crianças, nesse processo de trabalho, mostraram um forte sentimento de solidariedade e de préstimo quando produziram seus objetos. Cooperativas, estavam sempre dispostas a auxiliar uma à outra, fortalecendo laços de amizade e troca de interesses e informações.

Dei prosseguimento ao trabalho oficineiro utilizando novamente o livro "Cerâmica Guarani" de La Salvia e Brochado (1989). Uma ação pedagógica de se rever o conhecimento já aferido pelos participantes e que deu oportunidade de prepará-los para o recebimento de novos dados contíguos àqueles anteriormente aprendidos ${ }^{8}$. Como na última aula nos haviam detido no arranjo ungulado, agora esse estímulo se orientou na direção das técnicas do corrugado (belisco) e do escovado/estriado (raspagem). Observando-as nas fotografias, os curumins iniciaram o trabalho reconstruindo seus objetos e finalizando-os com esses métodos decorativos.

\footnotetext{
8 "O processo de aquisição da criança ocorre através da repetição das experiências bem-sucedidas, que tendem a reproduzir-se até o automatismo para só depois dar lugar a novas aquisições. No entanto, só se tornam hábitos ou técnicas de vida, eficientes e construtivas, se resultantes de uma experiência afetiva. Portanto, enquanto as regras que conduzem ao êxito não estiverem fixadas não é possível orientá-las pela educação" (ELIAS, 1997, p. 58).
} 
Para auxiliá-los, levei escovas como instrumentos alternativos para facilitar a aplicação da técnica do escovado. Mas qual não foi minha grata surpresa quando, muito naturalmente, parte dos meninos se apropriaram de gravetos espalhados pelo chão do pátio da aldeia para realizar a tarefa proposta! Algo que, empiricamente, eles acabaram por corroborar a práxis tradicional no processo de fabricação ancestral de seu grupo, mas para a qual, eu mesmo não havia me recordado e, obviamente, pensado em realizar. ${ }^{9}$

Já com indícios básicos sobre a morfologia cerâmica de seus ancestrais (métodos de construção e decoração), procurei atingir com os Mbyá o próximo estágio de meu planejamento de trabalho: o de proporcionar a eles o contato com o as técnicas de suas pinturas ancestrais. $O$ interessante a se ressaltar é que o urucum era conhecido por aquelas crianças menores como fruto do pé de urucum existente ali na Tekoa, mas seu atributo como fonte extratora de tinta só era dominado pelas crianças maiores. Foi-me uma descoberta surpreendente que esses curumins menores até então não houvessem tido contato direto com essa práxis pictórica de seu povo. Então os atentei a possibilidade de recolher a tinta da semente e de como pô-la adequadamente, cada um, nas suas peças. E creio que os etno-saberes sobre os grafismos Guarani usados na cerâmica, sendo orientados por alguém mais experiente, foram naquele momento bem transmitidos, facilitando melhor a apreensão desses meninos a respeito de parte da sua cultura material/imaterial.

Essa nossa reunião reforçou nos curumins a ideia da relação ensino/aprendizagem carregada de experimentação, de pesquisa sobre os movimentos estéticos que não haviam ainda sido explorados (as pinturas), nutrindo um grande entusiasmo em todos os participantes daquele dia. Por essa resposta positiva dos pequeninos, cri que houve o destaque merecido àquelas atividades, tornando minha intervenção metodológica de ensino proveitosa aos envolvidos.

Ademais, durante o conhecimento do processo "colorístico", elas foram levadas a associar a pintura dos objetos com um dos saberes prévios que já detinham de seu

\footnotetext{
${ }^{9}$ Monticelli (2007, p. 109) diz que os Guarani do passado - quanto a esta técnica do escovado (estriado) apresentavam obras com aplicação de 'estrias impressas' ou 'incisas na superfície quando ainda plástica', sempre paralelas entre si e com as distâncias iguais para um determinado número de estrias próximas, motivo pelo qual concluiu-se que teriam sido executadas por um instrumento semelhante a um pente."
} 
cotidiano: o da identificação da planta que deu origem à tinta usada e existente dentro da aldeia (o urucuzeiro), valorizando-o ainda mais como um patrimônio seu.

No que tange às cores, sabemos que sua diversidade de aplicação nos objetos se deve a presença de vários compostos físicos/simbólicos, onde determinadas imagens significam elementos ideacionais da cultura Guarani-Mbyá. E estas são mostradas ao mundo principalmente a partir do "[...] negro: extraído do jenipapo [...] para utensílios diversos e desenhos corporais, como para a cerâmica, plumária, petroglifos e tecidos [...]" (LA SALVIA; BROCHADO, 1989, p. 97). E como uma linguagem, os "[...] termos básicos da cor equivalem à abstração de aspectos perceptíveis de acordo com o critério arbitrário de significância [...]", até por que "[...] A cor na cultura é de fato exatamente esse processo de relacionar, e não de reconhecer [...]" (SAHLINS, 2007, p. 164).

Então me conduzi por essa linha de trabalho gráfico/cromático tradicional de sua cultura, me dedicando a educar os meninos nos desenhos e cores Mbyá, relacionando-os aos seus mitos e os ajudando, portanto, a refinar a sua percepção da sutil variação não só do tom utilizado (fundo vermelho, primeiro plano em preto), mas segundo os seus significados endógenos. Contudo, não pude usar o jenipapo para obtenção da tinta preta, já que dele não dispunha naquele instante, instrumentalizando-me de tintas industrializadas que levei para a oficina.

\section{Conclusão}

Enfim, pelas palavras e ações que travamos nessa pesquisa, creio que se reforçou diante dos pequenos Mbyá o valor patrimonial de sua obra cerâmica, o como e o porquê de terem sido aplicadas tais normas construtivas agregadas ao simbolismo das peças do passado, haja vista que há uma história (factual/ficcional) por trás de suas materialidades construídas.

Decerto esse procedimento oficineiro os favoreceu, ajudando no seu etnoconhecimento proposto enquanto mostra visual de ideias e de recursos com os quais seus ancestrais se relacionavam harmoniosamente com os seus iguais, com a natureza e com os seres ultra-humanos, criando um modelo de percepção, interpretação e de comportamento sociocultural. Devo ainda considerar que quando esses atributos se consolidam pela arte cerâmica na contemporaneidade Mbyá, acabam provocando um 
efeito multiplicador que pode se espalhar por toda a tribo como um saber atualizado e pertinente ao seu reconhecimento identitário.

Portanto, podemos tirar por conclusão parcial (pois a continuidade desse trabalho necessita ser realizada) que a arte cerâmica Guarani-Mbyá - prenhe de palavras/imagens - ocupa um papel de bandeira étnica onde, metaforicamente, homens marcam seus axiomas sobre a existência ligando-se emocionalmente a elas pelos atributos simbólicos que também são percebidos na morfologia dos seus objetos. $E$, tendo o respaldo mítico, a expressão artística indígena historicamente se presta a agir na educação comunitária tanto na realidade do dia a dia quanto na condução de elementos do plano físico para o seu mundo psíquico/espiritual.

No caso de ensino/aprendizado em Arte-Educação fomentado pelas oficinas oleiras na Tekoa, foi usando desse saber mítico prévio sobre o barro que as crianças puderam estruturar materialmente suas próprias licenças poéticas, criando e buscando resoluções para qualquer demanda que se the apresentassem nesse processo. Foi aliando dados sensíveis e intelectivos que se procurou proporcionar a elas a chance de, progressivamente, aprimorarem sua capacidade de pensar pelo barro e seus complementos afins (tratamentos e pinturas vistos e comentados junto a seus companheiros de atividades) sobre os fatos que identificavam ocorrerem à sua volta, levantando hipóteses, construindo inter-relações e conferindo suas suposições até diante de novas questões de friç̧ões interétnicas que lhes eram colocadas.

Creio que, diante desse contexto, qualquer tentativa juruá em desestruturar a cultura dos Guarani cai por terra, já que esses ameríndios mostram o quanto estão aptos a se adequarem, resilientes, frente as coerções políticas, comerciais, de fomento à sua invisibilidade etc. Os Mbyá estão, a meu ver, reelaborando seu cotidiano de modo a se acomodarem no mundo, congregando equilibradamente as relações entre todos os seus entes: humanos, natureza, artefatos, divindades.

Tudo flui de forma natural e adaptável para eles, transubstanciando de um corpo a outro aquilo que realmente Ihe importa: a essência do que entende por si mesmo e pelo que lhe seja uma alteridade. Esta, por sua vez, ainda é vista, repito, como integrada no corpus do mundo, não comprometendo em nada a aparência material que adquira nesse processo de demonstração de sua fé. Creio, portanto, que assim, 
para o Guarani-Mbyá, o artefato de barro pôde se desenhar em sua vida como um roteiro simbólico que explora o ontem, o hoje e o amanhã de sua cultura.

\section{Referências:}

ELIAS, M. D. C. CélestinFreinet: uma pedagogia de atividade e cooperação. Petrópolis: Editora Vozes, 1997.

FRADE, I. N.; REIS, M. Elementos da visualidade Guarani contemporânea: o artesanato em seu estado de dissolução. In: ENCONTRO DE PESQUISADORES PPGA/RJ; ENCONTRO DE ESTUDANTES DO PPGA/EBA/UFRJ, 1.; 17., 2010, Rio de Janeiro. Anais [...]. Rio de Janeiro: UFRJ, Escola de Belas Artes, 2010.

FRADE, I. N. O lugar da arte: o paradigma multicultural frente ao primitivismo. Textos Escolhidos de Cultura e Arte Populares, v. 1, n. 1, p. 17-24, 2004.

FRADE, I. N. Pedagogia do artesanato. Textos Escolhidos de Cultura e Arte Populares, v. 3, n. 1, p. 41-49, 2006.

GARLET, I.; ASSIS, V. S. A imagem do Kechuíta no universo mitológico dos MbyáGuarani. Revista de História Regional, v. 7, n. 2, p. 99-104 2007. Disponível em: https://www.revistas.uepg.br/index.php/rhr/article/view/202/139. Acesso em: 23 set. 2019.

GONÇALVES, J. R. S. Ressonância, materialidade e subjetividade: as culturas como patrimônios. Horizontes Antropológicos, v. 11, n. 23, p. 15-36, 2005. Disponível em: https://www.scielo.br/scielo.php?pid=S010471832005000100002\&script=sci_arttext. Acesso em: 23 set. 2019.

LA SALVIA, F.; BROCHADO, J. P. Cerâmica Guarani. Porto Alegra: Editora Posenato Arte e Cultura, 1989.

LADEIRA, M. I. Espaço geográfico Guarani-Mbya: significado, construção e uso. Maringá; São Paulo: Eduem; Edusp, 2008.

LAGROU, E. Arte indígena no Brasil: agência, alteridade e ralação. Belo Horizonte: Editora C/ Arte, 2009.

LEWKOWICZ, R.; PRADELLA, L. G. S. Algumas ideias equivocadas sobre povos 
indígenas e suas terras. In: PORTO ALEGRE, Assembléia Legislativa do Estado do Rio Grande do Sul / Comissão de Cidadania e Direitos Humanos. Coletivos Guarani no Rio Grande do Sul: territorialidade, interetnicidade, sobreposições e direitos específicos. Porto Alegre: Mesa Diretora Alrs; $\mathrm{CCDH}, 2010$. Disponível em: http://www.al.rs.gov.br/download/ccdh/coletivos\%20guarani\%20no\%20rs.pdf. Acesso em: 23 set. 2019.

MELIÁ, B. A história de um guarani é a história de suas palavras. Revista do Instituto Humanitas Unisinos on-line, v. 10, n. 331, maio 2010. Disponível em: http://www.ihuonline.unisinos.br/artigo/3258-bartomeu-melia-1. Acesso em: 12 maio 2019.

MONTICELLI, G. O céu é o limite: como extrapolar as normas rígidas da cerâmica Guarani. Boletim do Museu Paraense Emílio Goeldi: Ciências Humanas, Belém, v. 2, n. 1, p. 105-115, 2007. Disponível em: https://www.scielo.br/scielo.php?pid=S198181222007000100008\&script=sci_abstract\&tlng=pt. Acesso em: 12 maio 2019.

RAMOS, A. R. Sociedades indígenas. 2. edição. São Paulo: Ática, 1988.

SAHLINS, M. Cultura na prática. 2. edição. Rio de Janeiro: Editora UFRJ, 2007.

Enviado em: 25/05/2019

Aprovado em: 25/11/2020 